\title{
ANARCHOPHILIA, HEGEMONY AND INTERNATIONAL LAW
}

\author{
Rein MÜLLERSON*
}

RESUMEN: La guerra contra Iraq reflejó la urgencia de recurrir al multilateralismo para la solución de los problemas globales, por lo cual resulta necesario modificar al derecho internacional en algunos de sus fundamentos. La sociedad internacional se caracteriza actualmente por tener un poder hegemónico que busca fundar su legitimidad en la anarquía de las relaciones internacionales. Este escenario impone nuevos retos para el derecho internacional, que ante la ausencia de propuestas de solución, se ha limitado a fijar prohibiciones. En el campo de la paz y la seguridad internacionales, la responsabilidad de la creación de las leyes seguirá sometida a la voluntad del poder hegemónico y de sus simpatizantes, sin dejar mucho espacio al principio de igualdad soberana de los Estados, en un mundo en donde la coexistencia, más que la cooperación, rige las relaciones entre los mismos.

ABSTRACT: The war against Irak revealed the urgency to resort to multilateralism in order to solve the global problems, to which it is necessary to modify the International Law in some of its basis. The international society characterizes for having a hegemonic power which bases its legitimacy in the anarchy in the international system. This scene imposes new challenges to International Law, especially given its ineffectiveness to propose solutions, limiting itself to setting bans. In the domain of international peace and security the law-making role of most States will be limited to acquiescence in the practices of the hegemonic power and others. without leaving much space to the principle of sovereign equality of states or non-intervention, in a world where the law of co-existence more than the law of co-operation rules the relation among them.

RÉsUMÉ: La guérre contre l'Iraq a réflété l'urgence de recourir au multilatéralisme pour resoudre les problémes mondiales, pour lequelle c'est necessaire la modification du Droit Internacional de la base. La societé internationale se distingue par l'existence d'une puissance hégémonique qui fonde sa légitimité dans l'anarchie du systhéme international. Cé scène impose des nouveaux défis pour le Droit International, spécialement étant donné sa inefficacité pour proposer des solutions, et pas seulemente imposer des prohibitions. Dans le domaine de la paix et la sécurité internationales. le role des États en la création des lois continuerá être saisi à la volonté des États dans un monde ou la coexistence plus que la coopération guide les relations entre les mêmes.

* Professor of International Law, King's College, University of London, Member of the Institut de Droit International. 
SUMARIO: I. The Question of Hierarchy in an Anarchical Society. II. Anarchical and Hegemonic Fluctuations in International Societies. III. Benefits and Limits of Anarchy. IV. Swings of a Pendulum in International Society? V. Hegemonic Power and Hegemonic Legitimacy. VI. Hegemony and Anarchophilia. VII. Two Mines under International Law: US Unilateralism and European Anti-americanism. VIll. Leadership through Intermational Law and Institutions. IX. Legal and Political in the

War against Iraq. X. Conclusions.

After the end of the Cold War, the collapse of the Soviet Union and together with it of the bipolar international system and especially after 9/11 much has been written and talked about American hegemony, exceptionalism and even empire.' There is no doubt that within a decade or so the political configuration of the world has changed dramatically.

The war against Iraq shows that the US can do many things alone or in co-operation with a few allies. At the same time, the aftermath of the war and difficulties in re-building Iraq (or Afghanistan for that matter) show that acting unilaterally the United States may achieve rather quickly and effectively some short-term ends (mostly military-strategic ones) but that political and longer-term solutions to most important problems require multilateral efforts. It may not be by chance that one of the most influential conservative American foreign policy journals The National Interest in its first issue published in the aftermath of the 2003 war against Iraq carried several articles that emphasized virtues of multilateralism. David Calleo for example writes that "a global concert is urgently needed to manage the world's accumulating problems...".2

There is no doubt that radical changes in the world affect international law. Depending on the character and direction of such changes the latter may be either strengthened or weakened. If these transformations are of long-term nature, international law has to respond to them changing at least some of its fundamental premises. Therefore, the question today is how may current changes affect international law? Are they of

I See, e. g., Haass, R., The Reluctant Sheriff: The United States After the Cold War, Councit of Foreign Relations, 1998; Prestowitz, C., Rogue Nation: American Unilateralism and the Failure of Good Intentions, Basic Books, 2003; Layne. C., "America as European Hegemons", 72 National Interest (2003), at 17.

2 Calleo, D.. "Power, Wealth and Wisdom: The United States and Europe after Iraq", $72 \mathrm{Na}$ tional Interest (2003), at 15. 
such a nature that international law has to respond to them by transforming itself into something different from what we have known so far? My short answer is yes and no. No, in the sense that there is an invariable basic structure of international law that permits us to speak of international law. Yes, because some of the core institutions will undergo (or are already probably undergoing) quite significant changes.

In order to answer the question put above it would be advisable to step back and try to compare today's changes with some comparable earlier transformations in the world, since standing too close to the events may prevent one from seeing the wood behind the trees.

This article analyses some characteristics of international law in the context of the relationship between hegemonic elements and tendencies in international society and its basically anarchical character. Such an approach seems to be especially topical in the light of the preponderance of the United States in the world today and the unilateralist impulses of the Bush administration.

I would like to make it also clear that I am concentrating mainly on only one of the aspects of transformations taking place in international society. There are other changes that have to be kept in mind and that form an important context for the analysis of my focus.

\section{THE QUESTION OF HIERARCHY IN AN ANARCHICAL SOCIETY}

Any legal system, and international law is not an exception, functions as a normative subsystem of a wider social system (a state, a federal unit, an international or supranational organization, international society) that in the final analysis determines law's specific characteristics. International law's main features are moulded by the nature of international society. Being defined as an anarchical society ${ }^{3}$ it has not nevertheless been

3 Hedley Bull defines international society as interstate society: "A society of states (or international society) exist when a group of states, conscious of certain common interests and common values, form a society in the sense that they conceive themselves to be bound by a common set of rules in their relations with one another and share in the working of common institutions"; Bull, H., Anarchical Society: A Study of Order in World Politics, London, Macmillan, 1977, at 13. I agree with Hedley Bull's distinction between international system and society. As Adam Watson has succinctly summarized this distinction: "between the impersonal network of pressures and interests that bind states together closely enough "to make the behaviour of each a necessary element in the calculations of the others", which he [Hedley Bull] calls a system, and the set of common rules, institutions, codes of conduct and values which some or all of such states agree to be bound by, which he calls a society", Watson, A., The Evolution of International Society, London, Routledge, 1992, at 4. In this 
devoid of (hierarchical) or even hegemonic elements, tendencies or even periods. A perfectly anarchical society, i. e. society without any hegemony or hierarchy, could not even be a theoretical construct since it would simply be a non-society.

Speaking of hegemony and anarchy I imply nothing that is intrinsically either good or bad. For me they are social science terms and here they are not used, as journalists or politicians often do, in any pejorative sense. Hegemony is understood as authority, exercised by one or a few powerful states, that is able to determine the relations between the members of international society; authority that is able, though often, and especially today, more de facto than de jure, to "lay down the law" about the operation of the system. ${ }^{4}$ Speaking of anarchy I do not have in mind bomb-throwing terrorists but a political structure where units are not subject to any overarching authority that would be able to "lay down the law" for the system.

International society is a peculiar society. Its main actor -the stateis in a sense like a two-faced Janus whose functions may be characterized, using the words of Georges Scelle, as dedoublement fonctionnelle. ${ }^{5}$ On the one hand, the state belongs to international society, constituting its principal actor. On the other hand, the state is beyond international society: its internal structures and processes constitute the environment of international society affecting the latter from the outside, determining its main characteristics. The state does not wholly belong to international society and it is, in that respect, quite different, for instance, from another important actor of international society and subject of international law -the international organization-. The latter constitutes an integral part of international society. If states whose interactions form international society were not, at the same time, outside international society, there would not have been international (i. e. essentially interstate) society with its specific, quite unique characteristics.

article both of these terms are used depending on which aspect of the phenomenon is under consideration. However, as law reflects the societal aspects of the international system (ubi societas, ibi jus), more often the term international society is used.

4 Watson, The Evolution..., cit, supra nota anterior, at 15.

5 Scelle, G., Précis de droit des gens: principes et systématique, 2 vols., Paris, Sirey, $1932-$ 1934. 
I believe that Philip Allott somewhat underestimates the specificity of these characteristics of international society when he analyses international society as society side by side with other societies such as family, tribe and nation. He writes:

It is international constitutional law which determines the participants in the international legal system (for example, making a particular society into a "state"), and determines the conditions of their participation. The geographical and material distribution of constitutional authority among subordinate legal systems cannot be finally determined by those legal systems themselves, but only by a superordinate legal system, namely international constitutional law. ${ }^{6}$

From his point of view, "state-societies as subordinate societies of international society are delegates of international society".?

Here, it seems, Allott is taking the ideal for the reality. International society, unfortunately for international law and lawyers, and probably for the world as a whole, is not a superordinate society consisting of countless subordinate societies, as Allott writes, but secondary to, or derivative from, what Allott calls subordinate societies, i. e., states. International society does not create states but it is formed in the process of their interaction. John Gerard Ruggie's explanation of the relationship between states and international society seems to reflect the reality more precisely: "Because the institutionalization of authority takes place at the level of the state, and because jurisdiction is not transferred to some other entity but is exercised collectively by states", international authority may be conceived "as a transordinate structure, in contradistinction to superordinate and subordinate structures". 8

International society, in comparison with many other societies, is a rather loosely integrated or weak society. Its principal actors - statesare usually much more concerned with domestic issues than with external affairs. Their face that is turned towards international society is often secondary to the one turned inside. From that stems the most serious weakness or problem for international law. Logic requires, indeed, that domestic legal systems be subordinated to international law and in that sense

6 Allott, P., "The Concept of International Law", 10 European Journal of International Law (1999), at 37 y 38 .

7 Allott, P., Eunomia: New Order for A New World, Oxford University Press, 1990, at 256.

8 Ruggie, J., Constructing the World Polity, London, Routledge, 1998, at 61. 
Allott is right. A smaller system has to be subordinated to the wider system of which it is a part (at least in the sense that the former has to coordinate its functioning with the latter). Otherwise the wider system simply cannot function effectively. As Barry Buzan writes: "a holistic/system approach rests on the premise that the whole is more than the sum of its parts, and that the behaviour and even construction of its parts are shaped and moulded by structures embedded in the system itself". 9

Allott makes a similar point concerning the relationship between international law and domestic law: "It follows also that the three levels of the international legal system are a hierarchy, with international constitutional law having systemic supremacy, and with international public law dominating the exercise of legal powers within the national public realms, including the powers to make, apply and enforce national law". ${ }^{10}$ Logically, that should be so and international law, to be effective, should have always primacy over domestic legal systems, but actually the reality is often quite far from it.

Allott is closer to the truth when he, describing international society, uses the term "misconceived international society" describing it as "an unsociety ruled by a collective of self-conceived sovereigns whose authority is derived neither from the totality of international society nor from the people but from the inter-mediating state-systems". ${ }^{11}$ However, international society is not so much an "unsociety" than a "subsystem dominant" society 12 where units (i. e. mainly states) do not function as necessary parts of the whole. They are pursuing primarily their particular (so-called national) interests and not subordinating them to the interests of international society as a whole. This is not, of course, the best of the worlds we can imagine, but this is the world we live in. Moreover, the way of gradual improvement of the existing international society is not so much the creation of a better integrated superordinate society (though in many issue-areas and geographical regions this can and should be done) as the democratic empowerment of domestic societies.

9 Buzan, B., "The Level of Analysis Problem in International Relations Reconsidered", in Booth K. and Smith, S. (eds), International Relations Theory Today, Oxford, Polity Press, 1995, at 200 .

10 Allott, Eunomia.., supra nota 7, at 38.

11 Ibidem, at 249.

12 Kaplan, M., System and Process in International Politics, New York, John Wiley and Sons, 1967 , at 16 y 17 . 
Although international society is an anarchic horizontal society without a central governing body, it -like any complex and relatively stable system - needs at least some hierarchy of its component parts, notwithstanding what post-modernist or feminist writers may say about hierarchy. Only chaos is perfectly non-hierarchical. This applies to both natural and social systems. Ludwig von Bertalanffy, one of the founders of the systems theory, has put it very bluntly: "Reality, in the modern conception, appears as a tremendous hierarchical order of organized entities, leading, in a superposition of many levels, from physical and chemical to biological and sociological systems". ${ }^{13}$ Moreover, he believes that "such hierarchical structure and combination into systems of ever higher order, is a characteristic of reality as a whole and is of fundamental importance especially in biology, psychology and sociology". ${ }^{14}$

However, if some hierarchies are necessary and play mainly positive role, other hierarchies may be pathological and even dangerous like cancer. That is why philosophers distinguish between actualization hierarchies, whose function is to maximize the organism's potential, and domination hierarchies, which are based on force or the express or implied threat of force. ${ }^{15}$ In the latter case we have oppressive and usually also unstable hierarchical social systems. As an extreme example of an attempt to impose such dominance in international society was the Nazi regime's venture to extend its hegemony over Europe. This endeavour was not only bloody but rather short-lived too. Totalitarianism and authoritarian regimes in some societies are to a great extent based on pathological hierarchies ${ }^{16}$ where violence and threat of violence play important part in holding society together. However, in social systems it is not always possible to draw clear-cut lines between inevitable and necessary hierarchies and domination hierarchies.

The more perfect a social system, the less room there seems to be for any domination hierarchy. Nevertheless, as most of the social systems that have existed so far have been far from ideal; potential threat of force or its actual use has played some or even crucial role in all of them (this

13 Bertalanffy, L. von, General System Theory, New York, Braziller, 1968 at 87.

14 Ibidem, at 74 y 75.

15 Wilber, K., Sex, Ecology and Spirituality, Boston, Mass., Shambhala, 2000, at 26-32.

16 It is important to note that what is pathological in society and what is not depends on one's point of view or rather point of observation. Today, we may say that torturing people is wrong, criminal and pathological. However, some centuries ago torture was accepted practice of extracting confession for judicial purposes in most of societies. 
applies to both domestic and international societies). Is not the state itself often defined as the focus of legitimate use of violence? Anthony Giddens, having in mind domestic societies, writes that "there are respects, and some very important respects, in which the use of violence is necessary to achieve widely desired social ends". ${ }^{17}$

Contemporary liberal-democratic states use such legitimate violence sparingly and in principle do it, in principle, with the consent of the governed. As Barry Buzan and Richard Little observe, "at the unite level [i. e. in domestic societies], socio-political cohesion describes the degree of consensual integration between civil society and government. It is a measure of the extent to which coercion has been removed from the relationship between a citizenry and its governing institutions". ${ }^{18}$ But coercion in domestic societies has been removed only to a greater or lesser extent and even in liberal democratic societies elements of hierarchical dominance are, therefore, not completely eliminated. In less advanced societies they may be rather strong indeed, though even there they are not necessarily always imposed by force. Historical or religious traditions often play a legitimizing role in guaranteeing effectiveness of such hierarchical dominance. In international society, where illegitimate violence is quite widespread, there is also more room and sometimes even need for the use of legitimate violence. Phillip Bobbitt observes that "history discloses no examples of states that have given up the constitutional authority to deploy domestic or international violence without ceasing to be states". 19

Therefore, imperfect societies unfortunately but necessarily have elements of domination hierarchies that are based on various modalities of use of force or threat of force, videlicet they have rather strong hegemonic elements that guarantee their existence and functioning as societies. Hence, the question is not so much whether there is any hierarchy and hegemony in international society but how much of it, by whom, how and with what ends and motives it is exercised.

17 Giddens, A., Beyond Left and Right: The Future of Radical Politics, Polity Press, 1996 , at 230 .

18 Buzan, B. y Little, R., International Systems in World History: Remaking the Study of International Relations, Oxford University Press, 2000, at 410.

19 Bobbitt, P., The Shield of Achilles: War Peace and the Course of History, Penguin Books, 2002, at 206. 


\section{ANARCHICAL AND HEGEMONIC FLUCTUATIONS IN INTERNATIONAL SOCIETIES}

Historically, international society (or rather international societies since there have been many such societies and some of them have existed side by side not having significant contacts with each other as, for example, the Ancient Greek city state system and the Chinese Empire), has undergone constant transformations. Systems of political entities such as Ancient Greek city-states, Macedonian and Roman empires, the feudal Europe of multi-layered authority (the authority that was divided between the Papacy, the Holy Roman Emperor, various kings and princes in their relationships of suzerainty and vassalage) and systems of so-called nation-states (Westphalian international society) have all formed very different international societies. Even though continuously -albeit slowlychanging, international societies have always retained something that has made them different from domestic (intrastate, intratribal etc.) societies and that allows us to speak of them as international societies.

Such an invariable feature of any international society is that its main actors are political entities that are relatively independent from each other. Even when they have degrees of dependency, that is, when they are either highly interdependent (like the EU members states) or when some of them are more independent and dominant while others are more dependent (like various kingdoms and principalities in the Medieval feudal Europe), such entities nevertheless retain some degree of autonomy and therefore their relations are usually not governed by constitutions, edicts or other unilateral acts (though such acts may have some place in international societies too) but by various arrangements, agreements, treaties or customs that are based on at least formal consent or consensus.

Therefore, the term "laying down the law", which characterizes hegemonic authority in international society, cannot be understood as a legal term or a term that relates to formal sources of international law. In any international society, even in most hegemonic one, law and the process of its functioning have synallagmatic appearance: elements of at least formal reciprocity play a visible role. For example, even relations between a suzerain and his vassal -relations that even formally were not those between equals - were based on mutual arrangements quid pro $q u o$. The suzerain had to guarantee the security of the vassal against various external threats while the vassal had to perform sundry, including 
military, services to the suzerain. Hence, "laying down the law" means mainly, though not only, that a hegemonic authority has the ability to influence the content of international law, especially in those areas that matter most for the exercise of such authority. Issues of peace and security certainly belong to this category.

However, even in respect of the issue of the relationship between independence and dependency the distinction between international society and domestic (national) societies is not absolute. On the one hand, federal units may have more de facto autonomy in certain areas than sovereign states do and some of them even enjoy limited international legal personality; on the other hand, agreements may be one of the sources of the constitutional law of federal states. The creation and evolution of the EU (and the EC) society makes it even more difficult to draw sharp dividing lines between international and domestic societies. These distinctions are sometimes more of a degree than of substance (or rather differences in degree transform into differences in substance) and only the combination of various indicators, both empirical and legal, may help differentiate between international and domestic societies.

International society is a complex system where the various structural aspects of the system (i. e. whether it is a multipolar, bipolar or unipolar system, what role international institutions and law have, etc.) as well as the internal characteristics of its main actors (the domestic make-up of the different states) all play important role in the life of the system. Since internal characteristics of states, contrary to what realists among international relations theorists usually emphasize, greatly affect the nature of international society, ${ }^{20}$ no international society is like any other international society, though their structures may look similar. The Alexandrian or Roman Empires were very different from the British Empire and the anarchical Ancient Greek international society of city-states was only in some respect similar to the anarchical Westphalian society.

This means that when one concentrates on the study of the relationship between hegemony and anarchy in international society, one has also

20 The comparison of, for example, the European international society a hundred or even some sixty years back with today's Europe of the EU, Council of Europe and NATO shows more clearly than any other comparison how greatly internal and external characteristics influence each other. Today's Europe would not be a peaceful post-modern international society without its member-states being liberal-democratic free-market states and they would not all have had these characteristics without the new international (regional) structure. Hence, international depends on domestic, and vice versa, domestic depends on international. 
to bear in mind that these characteristics of international society, whatever their importance, are only one of the facets of international society. For example, Joseph Nye emphasizes the importance of quite a different tendency in today's world:

Privatization and public private relationship will increase. As we shape our policy in the information age, we will have to avoid being mesmerized by terms such as unipolarity and hegemony and by measures and strength that compare only the hard power of states run by centralized governments. The old images of sovereign states balancing and bouncing off each other like billiard balls will blind us to the new complexity of world politics. ${ }^{21}$

Therefore, this relationship has to be studied in the context of all other aspects of international society (both belonging to internal characteristics of its actors as well as to their external relations).

One of the constants of any international society has been certain fluctuation in degrees of dependences and independences of main actors of international society. Never being completely independent from each other, for then there would not be any society, they cannot be too dependent on each other either, for then there would not be international society.

Over long periods international society (or the various international societies, rather) has fluctuated between hegemonic and anarchic ends of the spectrum that may be described as: "A notional range of ways of organizing a system of states, from absolute anarchy or multiple independences to total centralization or empire. All known systems, and the rules of regulation and government, fall somewhere along the spectrum; the two extremes are theoretical and are not found in practice". ${ }^{22}$

For example, the Chinese, Macedonian and Roman empires were closer to the hegemonic $(\mathrm{H})$ end of the spectrum while Ancient Greek city states may have been, most of the time, closer to the anarchic (A) end of the spectrumnever, of course, reaching the very ends because otherwise there would have been either a superstate or chaos characterized by bellum omnium contra omnes. The European international society (so-called Westphalian society), which consolidated in the aftermath of the Thirty Years War and the Westphalian Peace Treaties of 1648, has had the ten-

21 Nye, J., The Paradox of American Power: Why the World's Only Superpower Can't Go it Alone, OUP, 2002, at 53.

22 Watson, A., The Limits of Independence: Relations between States in the Modern World, London, Routledge, 1997, at 150. 
dency to be closer than most international societies to the A end of the spectrum. Although there were hegemonic attempts (for instance by France under Louis XIV and Napoleon), such attempts were fairly effectively resisted by measures consistent with the political principle of balance of power. More successful was the joint hegemonic authority exercised after the Napoleonic wars by the members of the Concert of Europe (Austria, England, Prussia and Russia as a tetrarchy that became a pentarchy when France joined in in 1818). This last example shows that hegemonic attempts by a single actor may fail not only because of the lack of efficient power but also because such single hegemonic power may have bigger problems with its legitimacy than a hegemonic power that is exercised by a group of states. As I will try to show below, this observation is even truer in today's world than ever before.

The recent Cold War international society contained strong hegemonic elements. It was a kind of diararchy where the Soviet Union in the East and the United States in the West exercised their respective hegemonic powers -in the rest of the world, the two were competing. It is interesting to note that this was not something unheard of. In Ancient Greece, for example, Athens and Spartan led opposite hegemonic leagues - the Delian League was led by Athens and the Peloponnesian by Spartan. However, this comparison, though intriguing is, as Justin Rosenberg has written, one of a "gigantic optical illusion". ${ }^{23}$ It may serve more as an example revealing differences, which are conditioned mainly by the different nature of the units (the states) than revealing substantive similarities between seemingly identical structural arrangements. At the same time, this comparison shows that hegemony and hierarchy exist in various forms in otherwise rather different international societies. It also shows that crucial differences are less due to the structure of international society than to the nature of the actors of international society.

The Soviet Union itself was not an empire ${ }^{24}$ but a unitary state, notwithstanding that it had a written federal constitution. There was, how-

23 Rosenberg, J., The Empire of Civil Society: A Critique of the Realist Theory of International Relations, London, Verso, 1994, at 90.

24 Martin Shaw, however, writes that "Empire appears more as a relation between discrete national or ethnic groups, in which minority (or even majority) nationalities are subordinated by a state linked to the central nation. It has to be said, however, that from the standpoint of their minorities, virtually all modern states have had this imperial characteristic to a greater or lesser degree. Empire is, in this specific sense, a general characteristic of the modern state" (Shaw, M., "The Problem of the Quasi-Imperial State: Uses and Abuses of Anti-Imperialism in the Global Era", www.martins 
ever, a Soviet empire that consisted of its imperial core - the Soviet Union- and dependent states with degrees of autonomy such as Bulgaria, Czechoslovakia, Cuba, Hungary, Mongolia, Poland, etc. In contradistinction to the Soviet Union that was a highly centralized state, the Soviet Empire formed an international society -so-called socialist international society - where relations between its actors were governed by international law, the core of which consisted of principles of socialist internationalism that, for example, in the form of Brezhnev doctrine consecrated intervention in internal affairs "to protect socialist conquests".

Although the United States of America exercised hegemonic power over its allies or clients (Washington was especially effective in that respect in Latin America) its dominance over its allies could hardly be considered as imperial since states in the Western world had much more autonomy than Soviet allies in the Eastern bloc. If the Soviet hegemony was based more on power than legitimacy, the US hegemony, at least over its allies, had stronger legitimizing elements: for example the need felt by the US European allies - peoples and not only leaders - to have protection of liberal-democratic values and market economy from the communist threat. As Martin Shaw writes:

Ultimately the quasi-imperial character of the Soviet block [in my opinion, the Soviet block was an empire tout court] was a major contributory factor to its failure in the Cold War, in contrast to the success of the Western bloc. The superiority of the Western state form, which despite inequalities of power was based on genuine broad support in both national elites and society, was clearly demonstrated. ${ }^{25}$

One of the unexpected results of European dominance generally and especially of its colonial practices (i. e. European hegemony) has been the

haw.org/ empire.htm, visited 13 December 2002). In such a case, all multi-ethric states (i. e. most states) have had or still have imperial characteristics and Shaw considers states such as China, Russia, India, Indonesia and many other so-called Third World countries as quasi-imperial states because they include minorities with strong separatist tendencies and central authorities use repressive measures or even military force to keep reluctant minorities in. Shaw's analysis reveals that imperial characteristics can be present in such political entities as states. However, a state is not an empire (it may form the imperial core) and Shaw himself speaks of quasi-empires, $i$. e. of states with some imperial characteristics. On the other hand, empires may be seen also as units (though loose ones) in international society being at the same time also specific international societies; see Buzan y Little, International Systems..., supra nota 18, at 178.

25 Shaw, "The Problem of the...", supra nota anterior. 
expansion of the European anarchical international society that is based on the idea of sovereign nation states to practically all corners of the world, even where there were very few conditions for the emergence and natural evolution of such states. Consequently, there are what Robert Jackson calls "quasi-states" whose sovereignty is derived not internally from empirical statehood but externally from international society. Quasistates, where the "juridical cart" is pulling the "empirical horse", are to a great extent upheld by an external covenant among sovereign states. ${ }^{26}$ The presence of quasi-states, whose existence is due not to their internal strength, cohesion and survivability but to international society's efforts, evidences not only the significance of the role of international society vis-à-vis states but also the reality and strength of international law. The survival of quasi-states also undermines one of the basic tenets of the realist theory of international relations, namely that power is the only attribute of the state that really matters. Robert Jackson writes, "the key phrase 'in a democratic age' is not a statement of power but of legitimacy, of rights". 27 This assertion may go a bit too far, but at the same time, it is necessary to recognize that the sense of legitimacy is playing an increasingly important role in international affairs and, as we will discuss further, today it is a conditio sine qua non of any successful hegemonic authority.

Consequently, the colonial hegemony, ultimately and ironically, contributed to the increase of anarchy, though hegemonic factors and elements were never completely absent. As Adam Watson writes:

[A]ll through the twentieth century the rules of international society have inclined towards anarchy and rejected effective curbs on independence, especially in the periods of decolonisation: but the impersonal pressures of technology have been imposing stricter limits on the independence of member states, and pushing the system towards ever greater hegemonial authority. In the last decades, after the heady years of decolonisation, the system has in fact moved back from anarchic independence. The pendulum is an apt analogy for this to and for movement. Each swing builds up a tendency to swing back the other way. The swings take place over a considerable period of time, so that the movement in one direction seems more permanent than it really is. ${ }^{28}$

26 See Jackson, R., Quasi-States: Sovereignty, International Relations and the Third World, Cambridge University Press, 1990, at 168 y 169.

27 Ibidem, at 170 .

28 Watson, The Limits of Independence..., cit., supra nota 22, at 123. 
Today, this fluctuation between hegemony and anarchy is related to other binary opposite trends existing in international society such as universal versus particular or globalization versus fragmentation. There is, for example, serious tension between universal human rights and cultural and religious diversity, between economic globalization and various antiglobalization movements and effects, between American (and Western as a whole) dominance in the world and widespread resentment to this dominance that in its extreme form is expressed in terrorist attacks. These abstract categories reflect concrete everyday struggles that are constantly going on in international society.

The issue of anarchy and hegemony, like unipolarity or multipolarity, are primarily matters of fact and only secondarily are they questions of whether we like or do not like them. Certainly, if we do not like hegemony (or anarchy for that matter) and if we are able to alter the existing situation we may try to do that, but simply not liking it does not in itself unmake it. Moreover, the issue of polarity and whether a multipolar world is preferable to a unipolar world is not a simple question.

In 1997 China and Russia, for example, signed in Moscow a bilateral Joint Declaration on a Multipolar World and the Establishment of a New International Order, ${ }^{29}$ where they stated that "a positive trend towards a multipolar world is gaining a momentum". Igor Ivanov, the Foreign Minister of Russia, has emphasized that "the new architecture of international security should correspond to the multipolarity of today's world"..$^{30}$ However, there is very little multipolarity in today's world, especially in its military-strategic layer. And so, Jacques Chirac, the President of France, states that "it will above all be necessary to move toward a multipolar world". ${ }^{31}$ In these various statements what exists and what is desirable are confused.

It is understandable that Russia, as a former superpower, and France that has had a rather glorious international past, yearn for a multipolar system, in which they would serve the role of one of the poles. Smaller

29 See the Russian-Chinese Joint Declaration on a Multipolar World and the Establishment of a New International Order, adopted in Moscow on 23 April 1997, annexed to the Letter dated 15 May 1997 from the Permanent Representatives of China and the Russian Federation to the United Nations addressed to the Secretary-General, A/52/153-S/1997/384 (20 May 1997) available at www.fas.org/ news/russia/1997/a52-153en.htm (visited 13 December 2002).

30 Ivanov, I., The New Russian Diplomacy, Washington, D. C., The Nixon Centre and Brookings Institution, 2002, at 48 .

31 Idem. 
states, usually, seem to care much less about the polarity of the world. Therefore, it is not surprising that the main advocates of multipolarity are states that are not strong enough to play the role of the hegemon in the system as a whole (though they may be - or at least would not refuse to beplaying the role of a regional hegemon) but have enough power, at least potentially, to play the role of a pole. However, one would be rather naïve to doubt that, for example Russia, which is the continuation of the Soviet Union, would have refused to be the sole superpower in a unipolar world.

In any case, a multipolar world is almost by definition a world with rather considerable hegemonic elements and tendencies where hegemony is exercised not by one power but either jointly or separately by so-called poles. A multipolar system also presupposes the division of the world into respective spheres of interest or influence of polar-states. Therefore, those states that advocate multipolarity are not anti-hegemonic and proanarchic at all. They simply do not like somebody else's hegemony over them. Moreover, the more there are poles, the less stable would such a system be. The Cold War bipolar system was rather stable and it collapsed not due to any intrinsic systemic faults but because one of the poles happened to be deficient.

\section{BENEFITS AND LIMITS OF ANARCHY}

Let us now turn to the benefits and limits of anarchy. There are certainly positive sides in a system of multiple independences. David Landes, for example, observes that besides the split between secular and religious in the late Medieval Europe it was also fragmentation (i. e. anarchy) that played a positive role in the relatively rapid advancement of European societies:

Despotisms abounded in Europe, too, but they were mitigated by law, by territorial partition, and within states, by the division of power between the centre (the crown) and the local seigniorial authority. Fragmentation gave rise to competition, and competition favoured good care of good subjects... in those middle years between ancient and modern, fragmentation was the strongest brake on willful, oppressive behaviour. Political rivalry and the right of exit made all the difference. ${ }^{32}$ 
A system of multiple independences works, in a way, like market economy: on the one hand, various ideas and practices of how to arrange one's political and economic life compete and more successful practices (or elements of them) become examples to be followed (usually mutatis mutandis) and borrowed from. On the other hand, negative or disastrous experiments, like the Soviet or Nazi systems, may serve as warnings and examples not to be copied.

It is also that independence may satisfy visceral desires of ethnicities or other groups to have their own state and not to be governed by those who may profess a different religion, speak a different language or have different skin-colour notwithstanding that independence may not bring them any economic benefits or otherwise improve their situation at all. In the world dominated by the idea of nation-states, home-grown oppression is seen as more legitimate than externally imposed freedom.

Moreover, in some cases independent statehood may indeed increase individual freedoms and liberties or even give a boost for economic development. However, this is more an exception than a rule, especially, when secession is sought from democratic states. Today we have a situation when it is easier to secede from liberal-democratic states but there is less (if any) practical incentive for trying to do that. At the same time, there may be sometimes rather strong incentives for attempting to separate from dictatorships. However, it is not only difficult but it is almost always wrought with a threat of bloody wars whose outcome is usually rather inconclusive. Therefore, it is not accidental that today the principle of self-determination of peoples, which in the process of decolonisation supported the strive of colonial peoples and territories to independence, is more and more interpreted as a principle providing for democratic participation of all citizens in the social, economic and political life of the country without any discrimination whatsoever. Rather than being a right to exclusion (to have oneself excluded), the principle is now re-interpreted as a right to inclusion. Nobody should have a right to exclude other people on the ground of their race, ethnicity, religion, gender or, as it is becoming more and more recognized in Europe, on the basis of their sexual orientation.

Although the system of multiple independences (anarchy) may be conducive to the preservation of diverse ways of life (something akin to the value of biodiversity), it is not certain at all that every tradition in the rich tapestry of the social world is equally worth of being preserved. Hu- 
mankind's social experience includes torture, slavery, dictatorships, genocide, cannibalism, religious intolerance, racial and gender discrimination and other practices that today are contrary to widely accepted moral norms and to international law as well. Not every tradition is valuable, not every way of life can be preserved without accepting some kind of apartheid, i. e. parallel existence of mutually irreconcilable lifestyles. If developments in Europe show the way in some important respects for other continents we may see that not only certain practices but even ideologies may be outlawed. In autumn 1939, after the conclusion of the Soviet-Nazi non-aggression pact (together with the infamous secret protocols diving respective spheres of interest in Europe), the former Soviet Foreign Minister Vjatseslav Molotov declared that fascism has the right to existence (very soon, he would, of course, regret that he had ever uttered these words). Today, both fascism and to a great extent communism (at least as a practice) have been outlawed.

Under the norms adopted by the EU, Council of Europe, NATO and OSCE, the membership in these organizations is open only to liberal-democratic states with free market economy that respect basic human rights. This seems to indicate that in the ever closer and increasingly more inter-dependent world there is a widening normative limitation of the freedom of choice of social, political and economic systems. European development also shows that peaceful, democratic post-modern European international society is becoming less and less anarchical and more and more hierarchical.

It is interesting to note that today these are not liberal-democratic states that, extending their liberalism to interstate relations, emphasize the freedom of choice between different social, economic and political systems, but illiberal states that do that. For example, Russian-Chinese Joint Declaration on a Multipolar World and the Establishment of a New International Order, referred to above, declares that: "Every country has the right independently to choose its path of development in the light of its own specific conditions and without interference from other States. Differences in their social systems, ideologies and value systems must not become an obstacle to the development of normal relations between States". 33 
Here, of course, much depends on what is considered as "normal" relations between states. If, for example, not raising concerns about human rights violations in Chechnya is necessary for having normal relations, then relations between European countries are not normal at all. Moreover, in the interdependent world one's choice inevitably affects other countries. In today's international society, whether one chooses a totalitarian, oppressive and doomed-to-fail social, economic and political system (usually such choices are not made by people but by rulers only), or a democratic system based on human rights, cannot be an internal matter.

\section{SWINGS OF A PENDULUM IN INTERNATIONAL SOCIETY?}

At the end of the Cold War various authors offered different scenarios of the future world. Francis Fukuyama predicted the end of history, as liberal democracies would triumph. ${ }^{34}$ Barry Buzan and Gerald Segal wrote of the emerging "Westernistic" civilization. ${ }^{35}$ Samuel Huntington, on the contrary, foresaw a coming clash of civilizations. ${ }^{36}$ Many joined George Bush Sr. in welcoming a new world order, while others, like Ken Jowitt, ${ }^{37}$ emphasized the dominance of disorder in the post-Cold War world. There were also those who emphasized the emerging world's division between zones of peace and zones of turmoil. ${ }^{38}$ Some, like Charles Krauthammer, welcomed the "unipolar moment" in the history of humankind. ${ }^{39}$

The National Security Strategy of the USA (NSSUSA) of $2002^{40}$ has drawn on practically all of these scenarios, being, however, more balanced (and therefore, obviously, less exciting too). This is indeed an eclectic documentbut so is the world. This probably explains the diverse, even mutually exclusive, comments on the NSSUSA. Michael Hirsh, for example, writes that "the national security strategy, misportrayed by the

34 See Fukuyama, F., The End of History and the Last Man, London, Hamish Hamilton, 1992.

35 See Buzan, B. y Segal, G., Anticipating the Future: Twenty Millennia of Human Progress, London, Simon and Schuster, 1998.

36 See Huntington, S., "The Clash of Civilizations", 72:3 Foreign Affairs (1993), at 22-49.

37 See Jowitt, K., New World Disorder, Berkeley, CA, University of California Press, 1992.

38 See Singer, M. y Wildavsky, A., The Real World Order: Zones of Peace/Zones of Turmoil, Chatham, NJ, Chatham House Publications, 1993.

39 Krauthammer, C., "Unipolar Moment", Foreign Affairs, 1990, vol. 70, núm. 1, at 23-33.

40 The National Security Strategy of the United States of America, September 2002, Washington, DC, White House, at iii, the full document available at www.whitehouse.gov/nsc/nss.html (visited 13 December 2002). 
media as a declaration of hegemony (one New Yorker magazine writer called it a plan for a global police state), is actually most notable for its moderation". ${ }^{41}$ In reality, this is neither a map for a global police state, nor is it, of course, an example of moderation.

The NSSUSA, following Fukuyama, is premised on the belief that there is only one sustainable model for national success: freedom, democracy, and free enterprise. At the same time, this document recognizes that today's international system is less orderly and more volatile than the Cold War world and its security environment is not only more complex but it is also more dangerous ${ }^{42}$ (as, for example, Ken Jowitt or John Mearsheimer ${ }^{43}$ had predicted). However, the NSSUSA does not, probably out of political correctness or for the fear of creating a self-fulfilling prophecy, follow Huntington in stating that there is a clash of civilizations. The document says: "The war on terrorism is not a clash of civilizations. It does, however, reveal the clash inside a civilization, a battle for the future of the Muslim world. It is a struggle of ideas and this is an area where America must excel"' ${ }^{44}$ Yet, how can America excel in this area if this is purely other people's internal clash? Obviously, it is not a clash only inside Islam. Moreover, the promise to make freedom and the development of democratic institutions key themes in US bilateral relations (a noble promise but it is difficult to believe that even after $9 / 11$ the current US administration will take it seriously enough, especially because development of democratic institutions, i. e. nation-building requires longterm and multilateral involvement), combined with special emphasis on efforts to promote freedom of religion and conscience, ${ }^{45}$ will inevitably create, if not a clash, then at least considerable tension with some parts of non-western civilizations. Equally, there are widely differing views within the Western civilization on the ways how to promote and even of the possibility of promoting democracy and human rights in other societies, extending these values to regions where they have never existed before.

41 See Hirsh, Michael, "World View: America's Mission", Newsweek, Special 2003 Edition, December 2002February 2003 , at 12 .

42 Ibidem, at 13.

43 See Meisheimer, J., "Back to the Future: Instability in Europe After the Cold War", in LynnJohns, S. (ed.), The Cold War and After: Prospects for Peace, Cambridge, Mass., MIT Press, 1991, at 141-192.

44 The NSSUSA, at 31 .

45 Ibidem, at 4. 
According to the NSSUSA, and who could seriously argue with it, it is not only liberal democracies ${ }^{46}$ that have prevailed in the competition with communist ideology and practice, but it is first of all the US that possesses unprecedented and unequalled strength and influence in today's world. ${ }^{47}$ Judging by references in the NSSUSA to alliances like NATO, ANZUS, and the EU as well as to powers with great potential such as Russia, China and India, it is possible to conclude that the document is premised on what would be called a concept of qualified unipolar vision of the world. Instead of the Cold War bipolar hegemony -the USA exercising it in the West, the USSR doing the same in the East- today there is American hegemony that, as the document implies, is to be exercised preferably with as wide a support of the international community as possible but that should not prevent the United States from acting alone if necessary. ${ }^{48}$

This may be a specific republican and conservative (or neo-conservative) vision of the world and George W. Bush administration's foreign policy may not necessarily be continued by other administrations. In the American foreign policy of the moment there is certainly something that seems to be Bush, Cheney, Rumsfeld or Wolfovitz-specific. But even the Bush administration has been forced in practice to change its too bellicose and unilateralist rhetoric. However, it seems that especially after $9 / 11$ any US administration would rather more assertively than before exercise American hegemony. Means and methods may be, and they better be, different but their direction would hardly change considerably even if decision-makers change. One of the serious problems with US foreign policy

46 Barry Buzan and Gerald Segal conclude that the world is entering a period of "Westernistic" civilization. Responding to those who write of the decline of the US or Western influence in the world they ask: "But how can it be said that the West has had its day when it is Western ideas (state, market, science, nationalism, maybe democracy) that are going forward with such force?" (Buzan y Segal, Anticipating the Future..., cit., supra nota 35, at 185). East Asian states have been successful in their economic and social development due, to a great extent, to their creative use of some important Western ideas. It would be vacuous to make guesses at what may be the situation in the world in hundreds of years but it seems safe to say that in the foreseeable future those societies that will progress economically, socially, politically and even militarily will have to become in some important aspects more, not less, similar to contemporary Western societies. Buzan and Segal use the term "Westernistic" and not "Western" civilization meaning that though the influence of some important Western ideas would be paramount, the West itself will be open to change using, inter alia, the experience of other regions (especially that of East Asia), as well as by way of critical re-evaluation of its own experience. It is not so much Western states as Western by origin ideas like market economy, nation state, information technology, democracy and human rights that influence the world.

47 The NSSUSA, at 1.

48 Ibidem, at 6 . 
seems to be not so much its hegemonic tendencies or even the purposes of the exercise of American power but the way Washington does it.

It has to be emphasized that if there exists a power able to exercise hegemony it will always attempt to do that. Some historians have noted that "powers that find themselves able to lay down the law in a system in practice do so". ${ }^{49}$ How, where, for what aims and under what conditions they do that is, of course, an important question but there seems to be no question that in our interdependent world a state, or a group of states, that has the capacity to exercise hegemonic power will almost inevitably try to do that. Isolationism in today's world can be only temporary; after the $9 / 11$ it could be hardly an option at all.

One of the constants of international society's evolution over ages has been certain fluctuation in degrees of dependences and independences of main actors of international societystates. Never being completely independent from each other, for then there would not be any society, they cannot be too dependent on each other either, for then there would not be international society. Over long periods international society (or various international societies) has fluctuated between hegemonic and anarchic ends of the spectrum that may be described as "a notional range of ways of organizing a system of states, from absolute anarchy or multiple independences to total centralization or empire. All known systems, and the rules of regulation and government, fall somewhere along the spectrum; the two extremes are theoretical and are not found in practice". ${ }^{50}$ Today, after the long period of relatively anarchic stage of the development of international society that was followed by a short, in historical terms, period of dual hegemony of the USA and the USSR, and even a shorter spell of post-Cold War uncertainty, we seem to have indeed entered a unipolar world. As two American authors opine, "if today's American primacy does not constitute unipolarity, then nothing ever will". ${ }^{51}$ John Ikenberry writes that: "For some Americans, the belief that American sovereignty is politically sacred leads to a preference of isolationism. But

49 Watson, The Evolution..., cit., supra nota 3, at 291.

50 Watson, The Limits of Independence..., cit., supra nota 22, at 150.

51 Brooks, S. G. y Wohlforth, F. A., "American Primacy in Perspective", 81 Foreign Affairs (July/August 2002) at 20. 
the more influential view - particularly after September $11-$ is not that the United States should withdraw from the world but that it should operate in the world on its own terms". 52

Calls addressed to a hyper or superpower to curb its hegemonic power by references to the eventual change of the existing power ratio (since no hegemony is indeed perpetual) and appeals to it to behave as if acting "behind the veil of ignorance", creating by means of its today's activities patterns of behaviour applicable in a distant tomorrow when today's hegemon has lost its predominant position, are not very realistic. Such a future may not only be distant but it is also uncertain. States do not act today with the aim of making rules for a distant tomorrow. For example, they did not exercise innocent passage to create the right to innocent passage. The right to innocent passage emerged as a result of maritime powers de facto pushing the boundaries of freedom of navigation. States do what they do first of all because it is in their national interest to do that. Law emerges more as a by-product and vector of the pursuit of their interests and values. Appeals to a super (or hyper) power to behave with moderation lest other states use hegemon's patterns of behaviour for the justification of their own policies will hardly work either. However, it is much more realistic to try to persuade a hegemonic power that it is in its own interest, and not in a distant future but today, or at least foreseeable tomorrow, to take account of interests, values and sensitivities of other states and peoples.

\section{HEgEMONIC POWER AND HEgEMONIC LEGITIMACY}

Power has never been sufficient for even a medium-term exercise of hegemony, not even when overwhelming military power has been combined with the superiority in the economic, scientific and technological domains along with increasing cultural dominance. Admittedly, hegemony may in itself be also a cause of anti-hegemonic conflicts. To diminish the probability of such conflicts, hegemonic power needs more that just the ability to use military power or economic muscle. Legitimacy, the degree of acceptance of hegemonic power by those over whom this power is exercised, has always been an important element of any successful he-

52 Ikenberry, J. G., “American Imperial Ambition”, 81 Foreign Affairs (September-October 2002) 44-60 at 53 . 
gemony. Hence, there are two important elements of hegemonic authority: power and legitimacy. By and large, legitimacy has to follow power and not vice versa. Power without legitimacy would be like raw meat that can be eaten but that civilized people prefer to cook so as to avoid diarrhoea or other even more serious diseases; while legitimacy without power would be like gravy without meat: unnecessary if not impossible. Therefore, power has to find its legitimacy and adapt to it by admitting the latter's limiting and guiding rolelegitimacy, in its turn, will be further moulded by the exercise of power.

Contemporary international society has some particular characteristics, absent in previous international societies, which affect the exercise of hegemonic power, define its legitimacy and especially increase the role of legitimacy. The world (or international society) where the United States may, and obviously is going to, exercise hegemony has at least two important features that differentiate it from all previous international systems and affect the exercise of any hegemonic authority.

First, for the first time it is the whole world, notwithstanding even its division into zones of peace and zones of turmoil, that forms a single international system. Previous international systems (whether the Ancient Greek city states system or the Roman Empire or the European Westphalian system) were all territorially limited systems. Even the Cold War international system, though encompassing practically the whole world, consisted of two hostile sub-systems in which the authority of respective hegemons was exercised over substantial, but nevertheless limited, parts of the system. Moreover, the very hostility between opposing blocks served also as a factor legitimizing hegemonic power of the block leaders. The dual-divided hegemony (there have been also dual-joint hegemonies) during the Cold War could be exercised not only because the United States of America and the Soviet Union were militarily the two most powerful states but also because the two clashing ideologies - the free-market and liberal-democratic ideology versus the communist ideology - served as factors that legitimized the hegemonic authority of the United States and the Soviet Union respectively.

Today, for the first time in history we may speak of global hegemony. The exercise of such hegemony obviously calls for more power (and not only military) than any previous hegemony since here we talk about the hegemonic burden on a global scale. By the same token, however, it is more difficult for such a hegemon to have its power considered 
legitimate, if not by all states, peoples and their leaders (an impossible task, in my opinion), then at least by a sufficient majority of the states and peoples in the world "sufficient majority" in itself being an unclear concept that depends on concrete issues and circumstances.

Secondly, factors that would legitimize hegemony in today's world are different from legitimizing factors in previous international systems. They differ even from those factors that legitimized the recent American and Soviet hegemonies in the Cold War international system. In most ancient, and not so ancient, international societies, which were closer to the hegemonic end of the spectrum, one of the legitimizing factors was the hegemon's ability to guarantee relative order and security in the system. For example, it has been noted that security of trade routes and food supply, protection against barbarian raiders, provision of public goods (such as roads, promotion of lingua franca, standards for weights and measures) contributed to the emergence of empires.$^{53}$ Historically, it has been religion that has often played an important role in legitimizing hegemonic authority (for instance all members of the Concert of Europe were Christian powers while the legitimacy of the Ottoman Empire was to an extent based on Islam). William McNeill who has identified four key features necessary to make stable empires, ${ }^{54}$ enlists as the first factor the availability of a non-parochial ideology to help to consolidate an empire as a stable entity. The initial attempts, for example, by the Sumerians to establish a stable empire failed because various city-states had different Gods. Only when the Babylonians were successful in their claims that their God Marduk had overthrown all the other Gods were they able to establish hegemony over other Sumerian city-states. ${ }^{55}$ In today's global world, however, hegemony cannot be legitimized by religion since religion, uniting "us", also divides "us" from "them" and consequently cannot unite the whole world. Moreover, today, any power that aspires to have more or less lasting influence in the world has to face the challenge of anarchophilia.

53 See Buzan y Little, International Systems..., cit., supra nota 18, at 177; see also Watson, The Evolution..., cit., supra nota 3, at 37.

54 See McNeill, W., The Rise of the West: A History of the Human Community, University of Chicago Press, 1963.

55 See Buzan y Little, International Systems..., cit., supra nota 18, at 172. 


\section{HEGEMONY AND ANARCHOPHILIA}

American, or generally Western, ideology of free-market liberal-democracy, the defence of which had legitimized the US hegemony during the Cold War, has indeed been triumphant. However, this ideology is no longer sufficient for the legitimization of US hegemony. The reason for this is not only that in some societies there is significant resistance to ideas of democracy, liberalism and human rights. There is also a serious clash between unipolar power (even if exercised by the US together with some or even all of its NATO allies) and anarchophilia ${ }^{56}$ - anarchophilia being the deeply entrenched belief that independent statehood is something intrinsically good while any degree of dependency and any form of inequality between states is even less unacceptable than, for example, inequality between individuals-- Moreover, though the United States is today stronger, both in absolute as well as in relative terms, than during the Cold War when it was able to exercise hegemony only in a two-thirds of the world ${ }^{57}$ it is also weaker due to the same factor that has made it stronger - the disappearance of the Soviet Union-. Such an apparently nonsensical conclusion follows from the fact that the US Cold War allies are today less security dependent from Washington than they were before the collapse of the Soviet Union. Some American foreign policy moves may even increase security threats to the Western world as a whole. In the eyes of some Western Europeans Washington may be seen not so much a security guarantor as a security liability. As Peter Gowan writes, "the Soviet bloc collapse has had a number of negative consequences for the exercise of U.S. political dominance over the capitalist core" 58 because "the security dependence of Western Europe on U.S. military capacity ended with the disappearance of the Soviet Union". ${ }^{59}$ The last remark is

56 Barry Buzan and Richard Little have defined "anarchophilia", as "the disposition to assume that the structure of the international system has always been anarchic, that it is natural, and (more selectively) that it is a desirable thing", Buzan y Little, International Systems..., cit., supra nota 18, at 440 .

57 Immanuel Wallerstein writes that the Cold War "divided up the world into a Soviet zone that was about a third of the world, and the US zone that was two-thirds. It kept the zones economically separate and allowed them to shout at each other loudly in order to keep their own side in order, but never to make any truly substantial changes in the arrangement". Wallerstein, I., "U.S. weakness and the struggle for hegemony", Monthly Review, July-August 2003 (Imperialism Now), at 24.

58 Gowan, P., "U.S. hegemony today", op. cit., supra nota anterior, at 42.

59 Ibidem, at 43 . 
only partly true since there are other, including new, threats that have replaced the old Soviet threat against which Europe is once again in the same boat with America.

Anarchophilia is the expression of the idea of independence and sovereign equality of states that is not unrelated, in its origin, to the idea of freedom and equality between human beings. The emergence of the concept of equality between men (initially, of course, not amongst all men but only amongst some of them) was a powerful idea that almost inevitably, though slowly and gradually, led to the idea of equality between all men, between men and women, between persons belonging to different racial or religious groups and finally also between states. In its application to international law and relations these ideas may be grouped together, as Martti Koskenniemi does, under the label of liberal theory of international law. ${ }^{60}$

However, there is a strange, multi-dimensional and controversial relationship between individual liberties and independence of states (or other social groups, such as ethnic or religious minorities), and between equality of individual human beings and equality of states. In principle, the equality between individuals qua individuals and their freedoms may indeed be enhanced and supported by the recognition and advancement of equality between various social groups to which these individuals belong but usually it is the case only when these groups themselves recognize and protect freedoms of and equality between individuals. Quite often, however, governments of newly independent states embark upon human rights violations as soon as they are able to do that. Hence, independence for groups may well mean not more but less freedom for individuals. Although independence of some social groups may in fact mean less freedom for the members of these groups, ${ }^{61}$ those who fight for their independence are still invariably (but often wrongly) called freedom fighters -anarchy in international society has become equated with freedom-.

60 Koskenniemi, M., From Apology to Utopia: The Structure of International Legal Argument, Helsinki, Finnish Lawyers Publishing Company, 1989, at xvi.

61 It would be better not to confuse freedom and liberty, on the one hand, and independence, on the other. Although we quite often, and in various contexts, speak of independence of individuals, the words "freedom" and "liberty" cannot be properly used for the description of relations between social gtoups. For example, states may be independent, like North Korea, but not free, while some highly dependent small EU member states are among the freest in the world. 
As independence and sovereign equality of states is not the same thing and does not have the same value as freedom and equality of individuals, accepting the idea of equality of all states irrespective of their internal arrangements, notwithstanding their governments" behaviour vis$\grave{a}$-vis the governed we, in a way, compromise the ideal of equality of individuals as well as the ideal of universality of human rights. As we live in a non-perfect world, such a compromise is, to an extent, inevitable. While the principle of sovereign equality of states reflects the division of humankind into different groups, the principle of respect for human rights, and the very idea that there are some basic universal human rights, reflect the unity of humankind. No doubt, there is a contradiction and clash between these principles but for practical reasons compromises between them are necessary. At the same time, it seems that the more interdependent and smaller the world becomes, the less there will be room for such compromises and international human rights law is attempting to mark their limits.

Radical Islamic regimes, in power in some countries, for example, do not recognize equality between men and women. Moreover, they not only categorically reject the idea of equality between different religions (of course, practically no religion admits equal worth of other faiths) ${ }^{62}$ but also consider conversion of Muslims to another faith - that is, their exercise of freedom of conscience under Article 18 of the Universal Declaration of Human Rights or Article 18 of the International Covenant on Civil and Political Rights- as apostasy even punishable by death. If we admit that such Islamist attitude towards religious freedoms or gender equality has the same value as liberal-democratic worldview based on democracy, rule of law and human rights, we would betray the very idea and the ideal of equality between individuals.

The one-state-one-vote UN system with its principle of sovereign equality of states and non-interference in their internal affairs that is sometimes called a system based on liberal values and ideas is only superfi-

62 It seems that Jonathan Sacks. Chief Rabbi of the United Hebrew Congregations of the Commonwealth, at least implicitly acknowledges that all three main monotheistic faiths may have equal worth. He writes: "Religion is the translation of God into a particular language and thus into the life of a group, a nation, a community of faith. In the course of history, God has spoken to mankind in many languages: through Judaism to Jews, Christianity to Christians, Islam to Muslims... This means that religious truth is not universal": Sacks. J., The Dignity of Difference: How to Avoid the Clash of Civilizations, London. Continuum, 2002, at 55. However, his views have become an object of severe eriticism from the part of other rabbis. 
cially similar to the one-person-one-vote liberal-democratic systems. Such "liberal" international system that equally values and protects all the states notwithstanding their domestic characteristics favours the perpetuation of undemocratic and illiberal domestic societies ${ }^{63}$ and is contrary to the principle of respect for human rights.

This is not a call for overthrowing authoritarian governments but neither is it a validation or acceptance of the principle (rarely openly declared but nevertheless widely followed) that "peoples deserve their leaders". I cannot begin to imagine what sin the Cambodians could have committed to deserve Pol Pot, or the Ugandans to deserve Idi Amin, or the Iraqis to deserve Saddam Hussein. The world community, whether through its specialized organizations or individual states, must take seriously its communal obligations, including obligations in the domain of human rights.

However, notwithstanding these huge differences between liberties of individuals and degrees of independence of states, one would make a serious mistake if one were to neglect the influence of anarchophilia. The anarchic Westphalian international society may be coming to an end in Europe, where it emerged and developed, but in other parts of the world nationalism is on the rise, religious intolerance divides people even within states and the idea of a universal empire is even more utopian than the idea that states are, or should be, equal and independent in our interdependent and violent world. This means that even benign hegemony will be met with resistance - while every hegemony, if not facing any opposition, has a tendency to become less and less benign; hegemony, like power, corrupts and absolute hegemony corrupts absolutely-. The American hegemony will be met with resistance not only by those who may lose out as a result of the exercise of the hegemony (the likes of Saddam Hussein or even the Saudi Royal family stand to lose should Washington follow through its promise to promote freedom of religion and conscience and defend it from encroachment by repressive governments); ${ }^{64}$ the American hegemony will be resisted by also those who may benefit from it. This is not only because in the past Washington has often abused its po-

63 There is no space in this article to do justice to the complicated issue of liberalism in domestic societies and in international society. Therefore, I refer to my Ordering Anarchy: International Law in International Society, Kluwer Law International, The Hague, 2000, at 60-63, where I analyze views of Koskenniemi, Teson and Rawls.

64 Cfr. the NSSUSA, at 4 
wer; it is also because of the deeply entrenched ideas of equality and liberalism that have, rightly or wrongly (more often wrongly), been extended to relations between states - that is, because of our anarchophilia- As Buzan and Little write:

[T] dern state strongly underpins anarchy, as does the doctrine of nationalism as the centerpiece of political legitimacy. This is in sharp contrast to the unit effects in the ancient and classical world, where empire carried substantial legitimacy, and bandwagoning in pursuit of peace and order was as common as balancing to preserve independence. ${ }^{65}$

Ana The Economist observes that "[I]mperialism and democracy are at odds with each other. The one implies hierarchy and subordination, the other equality and freedom of choice. People nowadays are not willing to bow down before an emperor, even a benevolent one, in order to be democratised" 66

It has to be noted that though what Buzan and Little write is true in the case of modern states, there are also post-modern and even pre-modern states. Robert Cooper, a senior British diplomat, has written of premodern, modern and post-modern states that co-exist side-by-side in today's world.$^{67} \mathrm{He}$ speaks of the existence of "two new types of state':

[F]irst there are now states -often former colonies - where in some sense the state has almost ceased to exist: a "premodern" zone where the state has failed and a Hobbesian war of all against all is underway (countries like Somalia and, until recently, Afghanistan). Second, there are post imperial, postmodem states that no longer think of security primarily in terms of conquest. And thirdly, of course there remain the traditional "modern" states who behave like states always have, following Machiavellian principles and raison d'êtat (one thinks of countries such as India, Pakistan and China). ${ }^{68}$

65 Buzan y Little, International Systems..., cit., supra nota 18, at 333.

66 The Economist, 16 August 2003, at 21.

67 See Cooper, R., The Post-Modern State and the World Order, 2a. ed., London, Demos, 2000; id., "The New Liberal Imperialism", Observer, 7 April 2002; id., "The Post-Modern State", in Leonard, Mark (ed.), Reordering the World: The Long-Term Implications of September 11, London, The Foreign Policy Center, 2002.

68 Cooper, R., The Post-Modern..., cit., supra nota anterior, at 12. 
In the post-modern world --the world of the European Union- there are no security threats in the traditional sense (at least threats that would originate from within this world) and instead of power (or balance of power), law prevails; the traditional distinctions between domestic and foreign affairs have broken down; there is not only legal promise not to use force but the use of force between post-modern states has become almost unthinkable; their security is based on transparency, mutual openness, interdependence and mutual vulnerability. This is a new paradigm of international relations, which Western European nations have created only recently after centuries of wars, anarchy and exercising the policy of balance of power. The two World Wars that started in Europe have served as the main catalyst for the creation this new Kantian world, albeit in one region only. "Within the confines of Europe", writes Robert Kagan, "the age-old laws of international relations have been repealed. Europeans have stepped out of the Hobbesian world of anarchy into the Kantian world of perpetual peace" ${ }^{69}$

It is, of course, debatable to what extent this peace is perpetual but Kagan is right in emphasizing: "Consider again the qualities that make up the European strategic culture, the emphasis on negotiation, diplomacy, and commercial ties, on international law over the use of force, on seduction over coercion, on multilateralism over unilateralism" ${ }^{70}$ It seems that European states may indeed be the first group of states ready to sacrifice, though sometimes rather reluctantly, anarchy for the sake of peace, prosperity and human rights.

In short, though even the hegemonic power of even Alexander the Great or that of the Roman Empire had to be supported by hegemonic legitimacy, the nature of that legitimacy was rather different from and in a way even less significant than legitimacy that is necessary for the support of US hegemony. The emergence of the twin-brothers of democracy and nationalism, that are in a strange love-hate relationship, ${ }^{71}$ as well as

69) Kagan, R., "Power and Weakness: Why the United States and Europe See the World Differently", Policy Review, 2002, núm. 113, 3-28 at 11 .

70 Ibidem, at 10.

71 Writing about state-building in Western Europe, Adam Watson observes that "the self-assertion of the middle class in Europe took two forms: the demand for participation in government, and nationalism" and that "three related trends, towards nationalism, democracy and popular interest in external affairs, exercised an increasing iniluence on the European states system... The ideas of nationalism and democracy were refated"; Watson, The Evolution... cit., supra nota 3. at 291. However, today nationalism is more often a limitation on democracy than its conditio sine qua non. 
the extrapolation of liberal ideology to inter-state (inter-group) relations have made it impossible for anyone to exercise hegemony without the support of legitimizing factors that favour anarchy over hegemony. Today, hegemonic legitimacy has to take account of not only of the idea of individual rights and liberties but also of the idea of equality between and independence of states. Therefore, a balance to be struck should enhance individual liberty without unnecessarily curbing independence and formal equality of states.

\section{TWO MINES UNDER INTERNATIONAL LAW: US UNILATERALISM AND EUROPEAN ANTI-AMERICANISM}

In my opinion, the 2003 Iraqi campaign and the events that preceded it as well as the developments following it seem to highlight several important facts. First, they confirmed once again that the United States is militarily, and not only militarily, by far the most powerful state in the world. Washington can accomplish many things unilaterally, and as the processes in the Middle East or even in Africa indicate, if decisive action is needed and the US does not become involved then there is little chance for success. At the same time, these very events also show that Washington cannot accomplish everything alone and that even preponderant military power needs allies. Moreover, Rumsfeld's soundbite that it is not a coalition that dictates a mission but a mission that dictates the coalition is the surest way of creating anti-hegemonic, i. e. anti-American coalitions. Ad hocism in international politics lacks legitimacy and therefore undermines the effectiveness of power.

However, visceral, thoughtless and reactive anti-American is no less dangerous than American unilateralism. Especially damaging is antiAmericanism among American European allies. It is one thing to disagree with Washington on certain issues, to criticize the Bush administration over its concrete foreign policy steps and even vote against the US in the Security Council. But it is reckless for liberal democracies to try to counterbalance the US or to work against Washington on most acute security issues such as proliferation of WMD, terrorism, regional conflicts and problems created by regimes hostile to human rights and democracy. If it is exaggeration at all, then not a big one, to say that if Europe and the USA do not hang together then, at the end of the day, they may hang separately. 
The crucial question is: is it possible, and if yes then how, to reconcile and combine what seems to be American strength, decisiveness and single-mindedness that sometimes turns into simple-mindedness with European wisdom and sophistication that however not always helps against single-minded opponents of values such as democracy, rule of law and human rights. The first without the second may lead to actions not well thought through that usually neglect deeper and longer-term causes of world's most acute problems. It is also that the more unilateral the action, the less legitimate, other things being equal, it looks like. ${ }^{72}$ At the same time, wisdom and sophistication without the readiness to take tough and decisive actions may be impotent in the face of many imminent threats. Too much wisdom and sophistication, especially when they caution that certain things cannot be done since they have never been done before or because they have failed in the past, may become a recipe for inaction.

The basis that allows Europe and the United States to work together on most acute world problems is their common liberal democratic values -rule of law and respect for human rights-. The need for their combined efforts is conditioned by the fact that if liberal democracies do not work together on issues of peace, security and human development then life in many places of the world will indeed be nasty, brutish and short. Iraq under Saddam Hussein or North Korea under the Kims are classical examples of societies where regimes deny the peoples all so-called "Western values", but the West itself cannot remain a zone of peace and prosperity in the sea of conflicts, repression and poverty. Liberal democracies" working together does not mean at all that they work according to the formula "West against the rest". Today's adversary is not any specific state, group of states, culture or civilization. Today main enemies are phenomena expressed by general nouns such as terrorism, underdevelopment, ethnic violence and religious extremism. Therefore, liberal-democracies have to work together with the rest and for the rest too. However, if contradictions and even conflicts with some among the rest are almost inevitable due to the fact that not only their behaviour but also their values differ considerably form liberal democratic values, there is, in principle, less room for such value-based conflicts amongst the liberaldemocratic allies. Although there seem to be emerging some value-based

72 Of course, not only looks like, but also is since legitimacy is not an objective external yardstick to measure actions. It is subjective assessment, evaluation of actions in accordance with how one understands what is right and what is wrong. 
contradictions, different from interest based ones, between the Americans and the Europeans, these contradictions are (still?) relatively and comparatively minor.

There is no magic wand or legal formula that would make liberal democracies work together more effectively. Although there is the need for a Security Council reform and new institutions may be created and legal instruments adopted, none of these steps will lead to a breakthrough in the ability of liberal democracies to effectively influence the process of moulding a better world. They can do that only if they understand that what unites these societies is more important than what divides them, if they restore their faith in the primacy of their values and if they do not succumb to politically correct moral relativism. Fred Halliday, agreeing that the modernist enlightenment project, as envisaged earlier in the twentieth century, was inadequate and often crudely worked out and that many of the claims of reason were overstated, when not repressively imposed, quite correctly points out that these enlightenment concepts remain a foundation on which it is possible, and as he argues, necessary to build, as much as are our concepts of democracy, individualism, rights and tolerance. We should be prepared to redefine and defend them. ${ }^{73} \mathrm{He}$ also dismisses as inadequate responses derived from the critique of Western domination and ethnocentrism (the critique based on cultural relativism), from post-modern deconstructivist indeterminacy and from the camp of moral philosophy, which argue that one cannot be sure of any general moral principles. Rejecting the Enlightenment heritage because of failures and even crimes which may be associated with it would be not only wrong but also disastrous. We would be in a situation described by the Irish poet Yeats in The Second Coming:

Turning and turning in the widening gyre

The falcon cannot hear the falconer;

Things fall apart; the Center cannot hold;

Mere anarchy is loosed upon the world,

The blood-dimmed tide is loosed, and everywhere

The ceremony of innocence is drowned;

The best lack all conviction, while the worst

Are full of passionate intensity.

73 Halliday, F., Two Hours That Shook the World. September 11, 2001: Causes \& Consequences, Saqi Books, 2002, at 67-8. 
Working closely together, and not counterbalancing each other, is what liberal democracies have to do in order to lead the world in the struggle against terrorist attacks, ethnic violence, religious extremism, poverty, epidemics and environmental degradation.

However, one of the factors that make the smooth cooperation between liberal democracies that propound the same values more difficult is the fact that one of them is immensely more powerful than the others. Such a situation, on the one hand, creates the perception that one is almighty and may not need friends allies and, and on the other hand, raises the instinct of counterbalancing. However, liberal democracies should not behave like Sparta and Athens that, trying to counterbalance each other throughout the Peloponnesian war, paid little attention to the Persians what in today's world means terrorism, poverty, proliferation of WMD, etc.

\section{LEADERSHIP THROUGH INTERNATIONAL LAW AND INSTITUTIONS}

So, is there any room for hegemony at all in today's anarchophilic world, where independence, sovereignty and equality of states are the words so dear to so many people? My answer is: probably, there is.

Firstly, as it was explained above, if there is a state that is able to exercise hegemonic power such a state will almost inevitably try doing that. Moreover, in an anarchical international society (and international society is by definition an anarchical society) hegemonic authority (power accompanied by legitimacy) performs some functions analogical to those of governments in domestic societies. Hegemonies and hierarchies have almost always been present in international societies though their role has, of course, been a mixed blessing. However, today any successful hegemony, because of the reasons outlined above, has to be exercised through institutions and mechanisms that are to a great extent based on anarchical ideals. The irony is that anarchy has to be ordered by hegemonic authority, while hegemonic power has to be moderated, legitimized and limited by the recourse to instruments to a great extent based on anarchical ideas.

The war against Iraq shows that the US can do many things alone or in co-operation with a few allies. At the same time, the aftermath of the war and difficulties in re-building Iraq (or Afghanistan for that matter) 
show that acting unilaterally the United States may achieve rather quickly and effectively some short-term ends (mostly military-strategic ones) but that political and longer-term solutions to most important problems require multilateral efforts. It may not be by chance that one of the most influential conservative American foreign policy journals The National Interest in its first issue published in the aftermath of the 2003 against Iraq carried several articles that emphasized virtues of multilateralism. David Calleo, for example writes that "a global concert is urgently needed to manage the world's accumulating problems...".$^{74}$ Acting unilaterally and ignoring the issue of legitimacy of its behaviour the United States may be already in the process of squandering its potential as a "benign" hegemon. Christopher Layne, being worried (and rightly so I believe) about Bush administration's insensibility and hubris warns that:

The notion that the United States is a "benevolent" hegemon has been shredded. America is inviting the same fate as that which has overtaken previous contenders for hegemony. In the sweep of history, the Bush Administration will not be remembered for Baghdad, but for a policy that galvanized both soft and hard balancing against American hegemony. At the end of the day, what the administration trumpets as "victory" in the Persian Gulf may prove, in reality, to have pushed NATO into terminal decline, given the decisive boost to the political unification of Europe (at least the most important parts of it), and marked the beginning of the end of America's era of global preponderance. ${ }^{75}$

In today's world, international law and various international institutions are the only tools that can perform legitimizing functions. Although power moulds international law and institutions (sometimes even through violation of international law) the latter, while limiting and directing power, endow it with greater legitimacy and consequently with greater authority.

There is no doubt that radical transformations in the world affect international law. Depending on the character and direction of such changes the latter may be either strengthened or weakened. If these transformations are of long-term nature, international law has to respond to them changing at least some of its fundamental premises. Therefore, the question today is how may current changes affect international law? Are they of such a nature that international law has to respond to them by transfor-

74 Calleo, D., op, cit., supra nota 2, at 15.

75 Layne, C., op. cit., supra nota 1, at 28. 
ming itself into something different from what we have known so far? My short answer is yes and no. The answer is no, in the sense that there is an invariable basic structure of international law that permits us to speak of international law. One of its basic features is that it cannot be made or changed unilaterally, though we know that unilateral acts have a role in the process of international law-making. Think, for example, of the classical example of the role of the Truman Proclamation of 1945 in the process of the emergence of the legal concept of continental shelf. It has always been that some states are more equal than others in the process of the functioning (i. e. making, changing, observing, breaching and terminating its norms) of international law but if there is not even an appearance of consensus there is no international law either. The answer is yes, because some of the core institutions will undergo (or are already probably undergoing) quite significant changes.

\section{LEGAL AND POLITICAL IN THE WAR AGAINST IRAQ}

To understand better the Iraqi wars one should better distance him/herself from the immediate events and compare what has been going on in the Gulf region with some comparable events and processes in history. Otherwise, it is often difficult to see the wood of history behind the trees of events. It may be too early to understand properly the situation and only the passage of time will allow the true perspective to emerge. Was, for example, the Peloponnesian War that lasted from 421 to $404 \mathrm{BC}$ a war or was it a series of wars? Similarly, was the Hundred Years War between England and France, conventionally dated 1337-1453 a war or were there many different wars waged during this period between these parties? Did the participants understand that they were engaged in the Hundred Years War? Or what about the Thirty Years War of 1618-1648? It was, at times, even fought between different parties who, moreover, used to swap their alliances. Or moving closer to our days, was the war between the Soviet Union and Finland (the Winter War of November 1939March 1940) a part of WW II or, even more controversially, were World War I and World War II two different wars of the XX Century or were they rather composite battles of the same war that ended, as Phillip Bobbitt $^{76}$ writes, only in 1990 when the OSCE (then the CSCE) countries 
signed the Charter of Paris, which formally ended the division of Europe and resolved the main controversy of the previous epoch -one between liberal democracy and communism (the third main ideological competitor of the XX century — fascism - being defeated in 1945) -

In law it may be relatively easy to delimit wars in time as well as in space. It may be the case especially when wars start with declarations of war and end with peace treaties. The problem is that marking beginnings and especially ends of wars in political sense is much more difficult than delimiting them in legal or even military strategic terms. Most wars are not accidental skirmishes that due to no reason end up in mass slaughter. There are usually weighty economic, political (both domestic and international), religious or other ideological reasons and causes of wars. More often than not these causes and reasons are mixed and in political, not in military-strategic or legal, terms wars end when these causes or reasons have run their course, disappeared over time, or have been radically changed.

Juridical end of wars (through the conclusion of peace treaties, armistice agreements or adoption of Security Council resolutions) without resolving underlying causes of wars may be like sending peace-keepers to places where there is no peace to keep but where peace-enforcement, nation-building or regime-change are objectives of the day. In such circumstances juridical end of a conflict would be a palliative that may give temporary relief to those who are directly suffering from the conflict as well as satisfaction for outsiders who feel that something has to be done. The point I am trying to make is that in speaking of ends of armed conflicts, like of any other area of legal regulation, there should not be too big a cap between the law and politics, between normative requirements and the reality on the ground. This means that ending an armed conflict juridically, i. e. by concluding a peace treaty or adopting a Security Council resolution, without effectively addressing underlying political, economic, religious, inter-ethnic or other issues, may not end the conflict in political terms. Such a conflict may not necessarily restart, it may simmer, like the conflict between India and Pakistan over Kashmir or the divide between the North and South Korea, for many decades or even longer and sometimes, in changed circumstances, it may indeed eventually find a peaceful solution. Moreover, quite often one may be forced to live with temporary solutions, palliatives and containments because attempts to untie some Gordian knots once and for all may lead to catastrophic results. 
There are indeed precarious and potentially explosive situations that may be better to leave alone, but usually only for a while. However, it is necessary to understand that legal solutions, which retain underlying political problems unresolved, are temporary (and not always temporary solutions are most permanent) and that they do not end conflicts as political phenomena and that such conflicts may unexpectedly spring up throwing away the thin legal veneer that often rather inadequately covers boiling cauldrons.

Wars, especially if we spoke of what Phillip Bobbitt calls "epochal" wars ${ }^{77}$ but also almost of any significant regional armed conflict, end in political sense when the causes that underlie such wars have changed or circumstances contributing to their emergence transformed. In that respect Saddam Hussein's wars, even his war against the Iraqi people, especially against the Kurds in the north of the country, and even more so the 1980s war against Iran, to say nothing about the 1990-1991 Gulf War and the 2003 War, are only battles of the continuing conflict. The 1991 Gulf War (Operation Desert Storm) certainly achieved one of its declared purposes, viz. the liberation of Kuwait, but it manifestly failed to achieve the second and not less important purpose declared in Resolution 678 - "the restoration of peace and security in the area"-

The Israeli 1981 bombardment of the Oziraq nuclear power plant in Iraq may have been a setback for the regime's nuclear weapons programme but it did not resolve any underlying causes of the Iraqi behaviour. The liberation of Kuwait in 1991 and even following UN sanctions and enforcement measures did not resolve them either. They contained Iraq, they weakened it militarily but the conflict in the political sense certainly did not end in spring 1991 with the adoption of Resolution 687 or at some later date. I am not sure whether is has ended today. Maybe Resolution 1483 of 22 May or 1500 of 14 August , 2003 are more reliable legal documents marking the legal as well as political end of the conflict? But maybe not? The jury, probably, is still out.

The containment of Iraq by means of sanctions and weapons inspectors worked rather inadequately because they mainly hit a wrong target. They devastated the Iraqi people more than they contained the regime. As David Rieff recently wrote in the New York Times Magazine, "the pro- 
blem is that there is little or no evidence that sanctions do real damage to regimes that are willing to allow their people to suffer and die" ${ }^{78}$ Two UN humanitarian coordinators in Iraq under the sanctions regime. Denis Halliday and Hans von Sponeck, resigned in protest against the sanctions. The very lowest of many estimates of child death between 1990 and 2000 , caused by the rise of mortality rates from pre-Gulf War levels, is $100,000 .^{79}$ It is said that every Iraqi schoolchild knows what Madeleine Albright, the US Secretary of State at that time, told an audience in Ohio in 1996: "We think the price is worth it" ${ }^{80}$ It does not excuse us that it was Saddam Hussein's regime that had called these calamities upon the Iraqi people. Anti-terrorist operations are successful not when all the terrorists are killed but when their hostages are safely freed. Moreover, Rieff is not exaggerating at all when he concludes that "in many ways, Saddam Hussein became a master in manipulating the sanctions system to his own ends". ${ }^{81}$ The sanctions even helped Saddam to increase his grip of power over the Iraqis. When the regime is the main cause of a threat to peace and security then its containment is indeed only a palliative, maybe necessary one or, in concrete circumstances, the only one available but it is always a temporary solution. When a regime is the main cause of a threat to peace and security, efforts of its containment without a regime change may be a kind of Sisyphean toil.

A regime change, of course, should never be the only or probably even the primary motive for action and this rule has to govern not only actions involving use of military force. But if a regime by its behaviour threatens its neighbours or even far away nations, if its behaviour towards its own people shocks the conscience of humankind and if, in such circumstances, whoever it may be, takes an action such an action has to be carried through to its logical and necessary conclusions.

The situation in and around Iraq had become intolerable indeed and the main issue was not really the weapons of mass destruction (WMD) or that Iraq posed an imminent threat to the United States, Great Britain or to its neighbours. Saddam Hussein's alleged links with Al-Qa'ida seem to have been greatly exaggerated. The policy of containment had

78 Rieff, D., "Were Sanctions Right?", New York Times Magazine, 27 July 2003.

79 "Iraq Sanctions: Humanitarian Implications and Options for the Future", Global Policy Forum, New York. August 6, 2002.

80 The New York Review of Books, August 14, 2003, al 14.

81 Ibidem, at 5. 
failed miserably not because Iraq continued to be a threat but mainly because there was simply no any acceptable (acceptable by main players) way out of the situation. The continuation of the sanctions, though lawful, would have been immoral, ineffective and even illegitimate. Lifting sanctions, even if the weapons inspectors would have certified that Iraq did not possess prohibited weapons and weapon programmes, without a regime change would have been, in my opinion, unacceptable not only for the Bush administration. This would have meant victory for Saddam Hussein and he would not have failed to exploit it, especially in the Arab world.

Harold Koh, finding that Operation Iraqi Freedom violated international law, speaks of justifications put forward by the US and Britain: "the problem with both arguments [pre-emptive self-defence and references to Security Council Resolutions 678,687 and 1441] is that they disdain the need for political legitimacy in the strained quest for legal authority" ${ }^{82}$ Indeed, the main problem with these arguments is not that they are intrinsically wrong or absurd but that they are not accepted by most of the states and peoples. If in natural sciences, say, a Galileo or a Darwin may be right while the rest of us may be all wrong, in international law this cannot be so. Here Rorty's consensus theory of truth, not the correspondence to reality theory, prevails. Or to put it differently: consensus, even if sometimes more apparent than real, is one of the important elements of creation and functioning of international law. Attorney General's interpretation of international law is the correct one only if it is accepted by the audience it is addressed to.

It seems that the struggle and horse-trading within (and beyond too) the UN Security Council over Resolution $1441^{83}$ could have served as a good example of how power and legitimacy may interact. The US was threatening to use military force unilaterally or together with some of its allies to enforce previous UN Security Council resolutions in the case the Council failed to take effective measures to disarm Iraq. Here threats to ignore international law may have served, ironically, the purpose of enforcing international law. Power pushes the limits of legitimacy, but doing that power also attempts to secure implementation of international law. At the same time, the search for legitimacy also limits power: in this case the US became involved in the process of negotiations on the condi-

82 Koh, H., "Foreword: On American Exceptionalism". 55 Stanford Law Review (2003), at 1523.

83 SC Res. 1441, 8 November 2002. 
tions of use of force against Iraq. Unfortunately, in this case power and legitimacy departed: Washington together with a few allies used military force to overthrow the regime of Saddam Hussein. As Harold Koh writes, "Saddam's venality, Chirac's obstinacy and the United Nations fecklessness all deserve a good share of blame" ${ }^{84}$ But it was also American neglect of interests and sensibilities of other nations and not only on the issue of the Iraqi crisis. Washington's attitude towards the Kyoto Protocol, towards the International Criminal Court and its insistence that US servicemen and servicewomen be exempted from any threat, however remote, of being prosecuted by the ICC (the conclusion of so-called Article 98 agreements), and even US international trade policy had all made it more difficult for the United States to lead. However, the fact that in order to enforce the most important norms of international law and Chapter VII resolutions of the Security Council, it was necessary to threaten to violate international law or to by-pass the Council shows that there is something seriously wrong not only with American unilateral tendencies but also with both international law and institutions too.

\section{$\mathrm{X}$. CONCLuSIONS}

We seem to be entering, or we may have already entered, international society that is characterized by the following features: (a) it is a society where there is one hegemonic power - the United States-; (b) there are several regional centres of power like the EU, China, Russia and India; (c) this society is much more chaotic than the Cold War society (or the societies immediately preceding it) and this may contribute to the need for hegemonic authority — such an authority clashes with strong anarchophilia, however, and therefore the question of the legitimacy of hegemonial power becomes crucial-; (d) the most successful model of development is the Western model of free-market economy plus liberal-democratic political system - whose success, however, is often rejected and sometimes violently opposed by those who staying behind in this race (that, to an extent, is a "rat-race") for success and who see only negative aspects in what has made the West dominant--. How could international law respond to these rather new characteristics? 
One of the problems with international law is that especially in the domain of peace and security it is still, using the terminology of Wolfgang Friedmann, ${ }^{85}$ very much the law of co-existence rather than the law of co-operation. It contains prohibitions -not to use force, not to interfere in internal affairs- without mapping roads for solving problems. This defect of international law has become especially noticeable today when most threats to peace and security stem from "non-traditional" (by Cold War standards) sources such as terrorism and inter-ethnic as well as inter-religious conflicts. So, Gareth Evans and Mohamed Sahnoun are not wrong observing that "there were no agreed rules for handling cases such as Somalia, Bosnia, Rwanda, and Kosovo at the start of the 1990s, and there remain none today". 86

Though the Security Council may, in principle, decide or authorize use of even military force, and it has done so on several occasions; the Council has not always risen to a challenge. It is doubtful, for example, whether Resolution 1441 would have been adopted at all, had not Washington energized the Council (especially two of its permanent members, China and Russia) by threatening to by-pass the Council.

Law in international society will, by definition, remain based on various arrangements, agreements, and other forms of expression of will of states. Those are the invariable basis of international law. However, in the domain of international peace and security the law-making role of most states will be limited to acquiescence in the practices of the hegemonic power and other members of "the international executive". The principle of sovereign equality will remain a principle to which most states and experts pay lip service but in which only the most naïve will believe - today one would have to be very naïve indeed- The more serious an issue, the less is there room for the observance of the principle of sovereign equality of states. Compare, for example, the General Assembly with its one-state-one-vote system and Security Council with its veto power and permanent membership; or take international monetary institutions with their weighted voting systems; or EU inter-governmental bodies. Where money and security are at stake there is little room even for equality before the law, to say nothing about de facto equality.

85 Cfr. Friedmann. W.. The Changing Structure of International Law, New York, Columbia University Press. 1964.

86 Evans, G. y Sahnoun, M.. "The Responsibility to Protect", $81: 6$ Foreign Affairs (2002), at 99. 
The scope of internal affairs of states continues to narrow. The formula that states are free to choose their domestic political and economic systems will no longer hold true and certain choices will raise international opprobrium and various sanctions, especially if these choices affect other states. As to the changing character of norms governing use of military force, it seems that today the evolution of the domain of the legal regulation of use of force will most probably lead, at least in the medium term, towards the emergence of a kind of flexible (soft) jus ad bellum, in which the concept of legitimacy instead of legality is central, where the impact of a few specially interested states is crucial, where the legitimizing role of (the permanent members of) the Security Council remains noticeable, where the practice of some states and opinio juris of other states may considerably differ and where the frontiers between interstate and intrastate conflicts is becoming more and more blurred. Such a flexible set of guidelines that enjoys consensus among the majority of states and is supported by the world public opinion creates at least relative predictability in this domain - therefore it is preferable to "hard", definitive and clear rules that are not observed in practice-. 